\title{
Feed efficiency, growth performance, and carcass characteristics of a fast- and a slower-growing broiler hybrid fed low- or high-protein organic diets
}

\author{
Mehdi Rezaei • Jenny Yngvesson • \\ Stefan Gunnarsson • Lotta Jönsson • \\ Anna Wallenbeck $(\mathbb{D}$
}

Received: 8 December 2016 / Accepted: 3 February 2017 /Published online: 24 February 2017

(C) The Author(s) 2017. This article is published with open access at Springerlink.com

\begin{abstract}
Organic poultry meat production in Sweden is characterized by diets based on organic and locally produced feedstuffs, roughage allowance, a long rearing period (>10 weeks), outdoor access for the birds, and ban of synthetic amino acids and prophylactic use of antibiotics and anthelmintic. Until recently, the main hybrids used in organic broiler chicken production in Sweden were the same as used in conventional broiler chicken production. These birds are bred to reach market weight at 5 to 6 weeks on a high-protein quality nonorganic diet. In this study, organic high- and low-protein diets were fed to fast- and slower-growing hybrid broiler chickens with 5 pens per genotype $\times$ diet treatment and 21 to 22 broiler chickens per pen. Weight gain, feed conversion, health, and mortality were recorded during a 71-day rearing period. The fast-growing hybrid birds grew faster $(55.4 \pm 0.7$ versus $38.3 \pm 0.5 \mathrm{~g} /$ day, $P=0.001)$ and had a better feed conversion ratio $(2.6 \pm 0.1$ versus $2.9 \pm 0.1 \mathrm{~kg}$ feed $/ \mathrm{kg}$ body weight, $P=0.001$ ) than the slower-growing hybrid birds. The fast-growing hybrid birds grew slower when fed the high-protein compared to the low-protein diet
\end{abstract}

\footnotetext{
M. Rezaei · L. Jönsson · A. Wallenbeck

Department of Animal Breeding and Genetics, Swedish University of Agricultural Sciences, Box 7023,

SE-75007 Uppsala, Sweden

J. Yngvesson · S. Gunnarsson · A. Wallenbeck $(\bowtie)$

Department of Animal Environment and Health, Swedish

University of Agricultural Sciences, Box 234, SE-532 23 Skara,

Sweden

e-mail: anna.wallenbeck@slu.se
}

$(55.3 \pm 0.5$ versus $57.8 \pm 1.4 \mathrm{~g} / \mathrm{day}, P=0.050)$, while the slower-growing hybrid birds grew faster when fed the high-protein compared to the low-protein diet (39.4 \pm 0.7 and $37.2 \pm 0.4 \mathrm{~g} /$ day, $P=0.038)$. A higher proportion of fast- compared to slower-growing hybrid birds had sticky droppings at 1 week of age $(18.8 \pm 1.6$ versus $3.8 \pm 1.6 \%, P=0.001$ ) and were culled because of leg weakness during the 10 -week rearing period $(10.0 \pm 2.0$ versus $3.3 \pm 2.0 \%, P=0.031)$, indicating poorer welfare among fast-growing hybrid birds when reared for 10 weeks on organic diets.

Keywords Broiler - Growth - Mortality - Organic · Protein content $\cdot$ Slow-growing

\section{Introduction}

Consumer interest in organic animal products has increased in EU the recent (Blair 2008). Organic food production in Sweden is certified according to EU Council Regulation (EC) No. 834/2007 and in most cases also according to regulations by the Swedish organic certification organization KRAV (EC 2007; KRAV 2016). Organic broiler production is characterized by diets based on organic feedstuffs, roughage allowance, a long rearing period, outdoor access for the birds, and ban of prophylactic use of antibiotics and anthelmintic (EC 2007; KRAV 2016). The composition of organic broiler diets is dependent on availability and price of organic feedstuff, especially protein-rich feedstuff. As synthetic amino acids are not allowed in 
organic production (EC 2007), the amino acid profile in organic broiler diet is solely determined by the protein sources in the feedstuffs. Thus, the protein profile is not as optimized in relation to the protein demands of the bird as conventional broiler diets are, and organic broiler production has thus higher on-farm emissions of nitrogen per kilogram live weight (Bokkers and de Boer 2009).

Until recently, the broiler hybrids Ross or Cobb from crosses of Cornish and White Rock bird strains were solely used in both conventional and organic poultry production in Sweden. These fast-growing and highly efficient birds reach market weight for Swedish demands in 5 to 6 weeks (Aviagen 2014). Rearing these birds for the longer rearing period that organic rules require (i.e., $\geq 81$ days) may increase mortality and culling rate because of severe leg weakness associated with their rapid growth (Moyle et al. 2014; Eriksson et al. 2010). The long rearing period is set for several reasons, i.e., to promote use of slow-growing bird types and to meet the consumers' requirements of carcass size. One way to prevent the birds from growing fast is to apply restricted feeding. However, studies have shown that it is difficult to control the growth rate of these fastgrowing hybrids to the level required by organic production regulations (EC 2007). The nutrient requirements of fast-growing broilers are crucial, and if the diet is deficient in essential amino acids, over-consumption of feed may occur in an attempt to resolve the deficiency. This may lead to an over-consumption of protein which is not efficiently digested by the bird and thus lead to more nitrogen leakage to the surrounding environment (Morse 1995).

As an alternative to the fast-growing hybrids, slowergrowing genotypes could be more suitable for production systems with long rearing periods. Scientific data are limited on slow-growing genotype performance in Swedish organic production. Furthermore, the effect of feeding low-nutrient diets to fast- and slower-growing broiler genotypes has, as far as we know, not been studied in Sweden. Fanatico et al. (2005) described growth patterns for slow-, medium-, and fast-growing genotypes fed a non-organic diet in Italy, but scientific information about the effects of low-protein diet is still lacking.

The aim of the present study was to describe feed efficiency, growth, carcass characteristics, health, and mortality in broiler chickens of a fast- and a slowergrowing hybrid, fed high- and low-protein diets.
Furthermore, the aim was to assess effects of and interactions between these genotypes and diets.

\section{Material and methods}

Animals, housing, and management

In total, 431 birds entered the study. The study had a $2 \times 2$ factorial design where two genotypes (the slowgrowing hybrid Rowan Ranger $(N=211)$ and the fastgrowing hybrid Ross $308(N=220)$ ) and two diets (lowand high-protein content) were compared. Each genotype $\times$ diet combination was represented in 5 replicate pens with 21 or 22 chicks per pen. Chickens were not sexed at arrival; thus, the proportion of females/males in each pen was not known at the start of the project. However, gender was determined later in the rearing period and the average proportion of females in the pens were $56 \pm 7.6 \%$ (mean $\pm \mathrm{SD}$ ), without differences between genotypes, diets, or interaction between genotypes and diets $(P>0.05)$. The birds were housed in floor pens $(2.00 \times 2.00 \mathrm{~m})$ littered with $1 \mathrm{~cm}$ of wood shavings and containing three nipple drinkers and one hanging tube feeder. The initial temperature was $33{ }^{\circ} \mathrm{C}$ and was gradually reduced to a final temperature of $23{ }^{\circ} \mathrm{C}$ at the end of the rearing period. The relative humidity was maintained between 55 and $65 \%$ throughout the rearing period. The chicks had continuous artificial light during the first day, and thereafter, the dark period was gradually increased to 6 out of 24 h by day 8 .

Full requirements for organic broiler production were not met in this experiment regarding outdoor access and age at slaughter. In order to sustain a controlled experimental environment, the birds did not have outdoor access. Because of this, the birds were expected to have higher growth rates and live weights in the end of the rearing period compared to birds reared with outdoor access. As fast growth and high body weights are associated with lameness and mortality, the experimental slaughter age was set to 71 days instead of the 81 days requested in certified organic production. By doing so, the ethical requirements regarding reduction of unnecessary suffering of animals in experiments were followed, without compromising the scientific outcome of the study. The experiment was conducted from May to July 2015 at the Swedish Livestock Research Centre, Swedish University of Agricultural Sciences, LövstaUppsala. All procedures were approved by the National 
Ethics Committee for Animal Experiments (C9/15, Uppsala, Sweden).

Feeding

All birds were fed the same starter diet ad libitum for the first 2 weeks. From week 3, they received an experimental diet (ad libitum) which consisted of either a low-protein diet (low amino acid content) or a more conventional diet formulated according to NRC (1994) recommendations as a high-protein diet (Table 1). The crushed pellet feed did not contain any synthetic amino acids, coccidiostats, or antibiotics according to organic standards. The 4 treatment groups consisted of slow-growing Rowan Ranger birds fed the low-protein diet (RRL), slowgrowing Rowan Ranger birds fed the high-protein diet (RRH), fast-growing Ross 308 birds fed the low-protein diet (RL), and fast-growing Ross 308 birds fed the high-protein diet (RH). Each pen of birds was provided with $2 \mathrm{~kg}$ pelleted straw per week as a roughage substitute. Straw pellets were provided as roughage instead of silage or hay to ensure that the protein consumed originated from the treatment diets.

\section{Data recording}

Birds and feed were weighed every week for determination of growth rate, feed intake, and feed efficiency at pen level. At 70 days of age, all birds were individually weighed to determine within-pen variation in bird weight. General health, mortality, and culling rate (including reason for culling) were recorded continuously throughout the rearing period. The reason for culling birds was irreversible injury or disease. In total, 10 birds were found dead of which 9 were sent to the Swedish National Veterinary Institute for autopsy. Pooled feces samples were collected at 4, 7, and 10 weeks of age for determining number of coccidia oocytes per gram feces. Feces from 7 or 8 pens located in one quarter of the house were pooled to 1 sample (in total 4 samples from the entire stable per sampling occasion). The samples collected in week 10 were also analyzed for Salmonella sp. At 1 week of age, the proportion of birds with sticky droppings (defined as feces attached around or close to the cloaca of the bird) was recorded in each pen.
Table 1 Composition and nutrient content of the two organic diets (low and high protein)

\begin{tabular}{|c|c|c|c|}
\hline & \multirow{2}{*}{$\begin{array}{l}\text { Starter (day } 0 \text { to } \\
\text { 14) }\end{array}$} & \multicolumn{2}{|c|}{ Grower (day 14 to 70 ) } \\
\hline & & $\begin{array}{l}\text { Low } \\
\text { protein }\end{array}$ & $\begin{array}{l}\text { High } \\
\text { protein }\end{array}$ \\
\hline $\begin{array}{l}\text { Metabolizable energy } \\
\quad(\mathrm{MJ}) \\
\text { Ingredients }(\%)\end{array}$ & 12.5 & 11.2 & 11.3 \\
\hline Wheat & 33.64 & 27.97 & 40 \\
\hline Soybean meal & 29.55 & 0 & 11.96 \\
\hline Rapeseed & 10 & 0 & 0 \\
\hline Oats & 8 & 45.01 & 24.63 \\
\hline Potato protein & 5.53 & 2.65 & 0.94 \\
\hline Limestone flour & 1.73 & 2.21 & 2.28 \\
\hline Peas & 0 & 12 & 12 \\
\hline Rapeseed cake & 0 & 5.5 & 1.88 \\
\hline Corn & 4 & 0 & 0 \\
\hline Fish meal & 2 & 0 & 0 \\
\hline Grass meal & 2 & 1 & 1.37 \\
\hline Soybean oil & 0.8 & 0 & 0 \\
\hline Corn gluten meal & 0 & 0.87 & 2.28 \\
\hline $\begin{array}{l}\text { Monocalcium } \\
\text { phosphate }\end{array}$ & 1.61 & 1.69 & 1.55 \\
\hline Premix $^{\mathrm{a}}$ & 0.65 & 0.65 & 0.65 \\
\hline Sodium bicarbonate & 0.29 & 0.28 & 0.2 \\
\hline $\mathrm{NaCl}$ & 0.2 & 0.18 & 0.26 \\
\hline \multicolumn{4}{|l|}{ Nutrient contents (\%) } \\
\hline Crud protein & 24 & 14.5 & 17 \\
\hline Lysine & 1.43 & 0.68 & 0.8 \\
\hline $\begin{array}{l}\text { Methionine + } \\
\text { cysteine }\end{array}$ & 0.9 & 0.63 & 0.67 \\
\hline Methionine & 0.43 & 0.27 & 0.3 \\
\hline Threonine & 1.02 & 0.57 & 0.65 \\
\hline Linoleic acid & 4.5 & 1.4 & 2.2 \\
\hline Crude fat & 0.91 & 0.45 & 0.37 \\
\hline Calcium & 1.1 & 1.3 & 1.2 \\
\hline Phosphorus & 0.8 & 0.71 & 0.7 \\
\hline $\begin{array}{l}\text { Available } \\
\text { phosphorus }\end{array}$ & 0.45 & 0.42 & 0.41 \\
\hline Sodium & 0.18 & 0.16 & 0.17 \\
\hline
\end{tabular}

From 0 to 14 days, all chickens received the same starter diet. All diets were commercially available organic diets containing $95 \%$ (of dry matter) organically certified ingredients

${ }^{\text {a }}$ Supplied per kilogram of diet: vitamin $\mathrm{A}$ (12,000 IU), vitamin $\mathrm{D}_{3}$ (3300 IU), vitamin $\mathrm{E}(150 \mathrm{mg})$, vitamin $\mathrm{K}_{3}(4 \mathrm{mg})$, vitamin $\mathrm{B}_{1}$ (3 $\mathrm{mg})$, vitamin $\mathrm{B}_{2}(7 \mathrm{mg})$, vitamin $\mathrm{B}_{6}(4 \mathrm{mg})$, pantothenic acid (12 mg), folic acid (1 mg), niacin (42 mg), choline (216 mg), $\mathrm{Cu}$ (16 mg), Co (0.25 mg), Mn (123 mg), Zn (105 mg), I (1.3 mg), Se $(0.7 \mathrm{mg})$, and $\mathrm{Mg}(1.8 \mathrm{mg})$ 
At 71 days of age, the birds were slaughtered by electric stunning followed by bleeding. Individual live body weight before slaughter and slaughter weight (carcass without intestines, heart, proventriculus, gizzard, liver, head, neck, and feet) were recorded for five randomly selected birds per pen. In addition, weight from one breast and one leg was recorded for two birds per pen. Breast meat included only breast meat, without skin, while leg meat included meat and bone of the upper leg, without skin.

\section{Statistical analysis}

Statistical analyses were performed using SAS (version 9.2; SAS Inst. Inc., Cary NC, US). Descriptive statistics were estimated using PROC FREQ and PROC MEANS. Differences between hybrids and diets and interactions between hybrids and diets were analyzed with general linear models using PROC GLM and with pen as study unit. Body weight gain, feed intake, and feed conversion ratio were analyzed using model 1 . Pen mean live weight the day before slaughter, live weight at slaughter, carcass weight, dressing percentage, percentage breast and leg in the carcass, percentage of birds culled because of leg weakness, and percentage of birds with sticky droppings at 1 week of age were analyzed using model 2 . Weight variation in the pen at slaughter was analyzed using model 3 . The following models were used:

Model 1: $y=\operatorname{diet}+$ genotype + genotype $\times \operatorname{diet}+$ age $+e$

Model 2: $y=$ diet + genotype + genotype $\times \operatorname{diet}+e$ Model 3: $y=$ diet + genotype + genotype $\times$ diet + pen mean weight the day before slaughter $+e$

where diet (high or low protein), genotype (Ross 308 or Rowan Ranger), and the interaction between diet and genotype were included as fixed effects. Age at measurement was included as a repeated measure and pen mean weight the day before slaughter was included as a continuous covariate.

Residuals of all dependent parameters in the analysis of variance were examined for normal distribution using PROC UNIVARIATE, considering the Shapiro-Wilk test for normality and a normal probability plot, and all were found to be normally or approximately normally distributed.
Results are presented as least square means with standard errors $(\mathrm{LSM} \pm \mathrm{SE})$ if nothing else is stated.

\section{Results}

Growth rate, feed intake, and feed conversion ratio

The Ross birds had a higher growth rate than the Rowan Ranger birds, resulting in higher mean live weight and carcass weight at slaughter (Fig. 1). Analysis of the interaction between hybrid and diet for growth rate $(P=0.002)$ showed that Ross birds grew slower when fed the high-protein feed than when fed the low-protein feed $(55.3 \pm 0.5$ versus $57.8 \pm 1.4 \mathrm{~g} /$ day, $P=0.050)$. However, Rowan Ranger birds grew faster when fed the high-protein feed than when fed the low-protein feed $(39.4 \pm 0.7$ and $37.2 \pm 0.4 \mathrm{~g} /$ day, $P=0.038)$. There were no differences between hybrids or diets and no interactions between hybrid and diet regarding within-pen variation in live weight at slaughter.

Over the 10 week rearing period, Ross birds consumed more feed than Rowan Ranger birds, while feed intake was not affected by protein level in the diet (Table 2). The feed conversion ratio was lower for Ross than Rowan Ranger birds but did not differ between high- and low-protein diets (Table 2).

\section{Carcass characteristics}

There were no differences in dressing percentage or proportion of leg meat in the carcass between hybrids and diets and no interactions between hybrid and diet. The proportion of breast meat in the carcass was higher among Ross than Rowan Ranger birds (Table 2).

Mortality and sticky droppings

Of the 431-day-old chicks entering the study, 42 died or were culled before slaughter. Out of these birds, 10 were found dead and 29 were culled due to severe leg weakness (Fig. 2). The other reasons for culling were general weakness (two birds) and congenital malformation (one bird). The proportion of birds culled because of leg weakness was higher among Ross than among Rowan Ranger birds $(10.0 \pm 2.0$ and $3.3 \pm 2.0 \%$, respectively, $P=0.031)$ and tended to be higher among birds fed the low-protein diet than among birds fed the high-protein $\operatorname{diet}(9.2 \pm 2.0$ and $4.1 \pm 2.0 \%$, respectively, $P=0.092)$. 


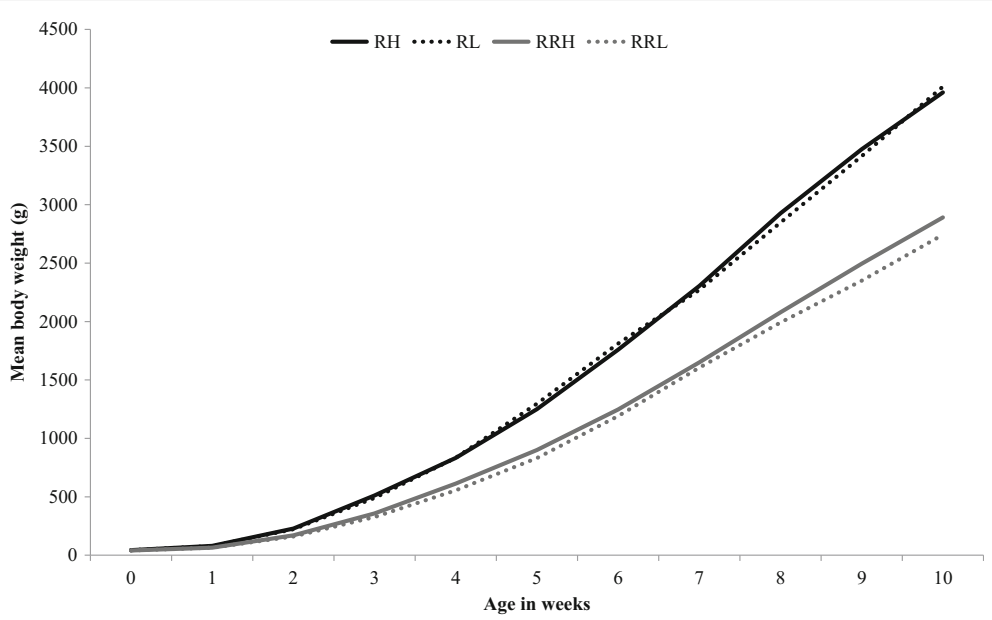

Fig. 1 Average chicken body weight per pen and week at 0 to 10 weeks of age (LSM) among fast-growing Ross birds fed the high-protein diet $(R H)$, Ross birds fed the low-protein diet $(R L)$,

A larger proportion of Ross birds than Rowan Ranger birds had sticky droppings at 1 week of age (18.6 \pm 1.6 and $3.8 \pm 1.6 \%$, respectively, $P=0.001$ ), and the proportion was lower among birds fed the low-protein diet than among birds fed the high-protein diet $(8.7 \pm 1.6$ and $13.8 \pm 1.6 \%$, respectively, $P=0.042$ ). Apart from the birds culled or found dead, no health problems were observed. Coccidia were not detected in any of the pooled feces samples collected at week 4,7 , or 10. Salmonella was not detected (only tested in week 10). At postmortem examinations of nine birds found dead, five birds had unspecific hepatitis, one had ascites, one had sepsis, one had volvulus of the small intestines, and one bird had negative findings. slow-growing Rowan Ranger birds fed the high-protein diet $(R R H)$, and Rowan Ranger birds fed the low-protein diet $(R R L)$. $N=20$ pens per week

\section{Discussion}

Growth performance, feed intake, and feed conversion ratio

The feed treatments used were commercially available organically certified diets. These were chosen to increase the relevance of the results for commercial organic broiler producers. As expected from hybrid standards, the fast-growing Ross birds demonstrated higher daily weight gain than the slow-growing Rowan Ranger birds, resulting in higher body weight at slaughter and higher carcass weight. These results confirm previous

Table 2 Feed intake and feed conversion over the 10 week rearing period and carcass composition in the high-protein $(\mathrm{H})$ and low-protein (L) diets and in the fast-growing (R) hybrid and slow-growing (RR) hybrid

\begin{tabular}{|c|c|c|c|c|c|c|}
\hline \multirow[t]{2}{*}{ Variable } & \multicolumn{3}{|c|}{ Diatary protein level } & \multicolumn{3}{|l|}{ Hybrid } \\
\hline & $\mathrm{H}$ & $\mathrm{L}$ & $P$ & $\mathrm{R}$ & $\mathrm{RR}$ & $P$ \\
\hline Daily feed intake (g/day) & $127.8 \pm 0.60$ & $126.5 \pm 6.80$ & 0.769 & $143.7 \pm 3.73$ & $110.6 \pm 1.78$ & 0.001 \\
\hline Feed conversion ratio ( $\mathrm{kg}$ feed/kg weight gain) & $2.8 \pm 0.03$ & $2.7 \pm 0.10$ & 0.489 & $2.6 \pm 0.05$ & $2.9 \pm 0.04$ & 0.001 \\
\hline Weight 1 day before slaughter (g/bird) & $3426 \pm 50.8$ & $3377 \pm 50.8$ & 0.200 & $3986 \pm 50.8$ & $2817 \pm 50.8$ & 0.001 \\
\hline $\begin{array}{l}\text { Standard deviation in weight in the pen } 1 \text { day before } \\
\text { slaughter (g/pen) }\end{array}$ & $436 \pm 25.0$ & $467 \pm 25.0$ & 0.402 & $414 \pm 75.6$ & $490 \pm 75.6$ & 0.611 \\
\hline Live weight at slaughter (g/bird) & $3467 \pm 120.2$ & $3239 \pm 120.2$ & 0.414 & $4050 \pm 120.2$ & $2656 \pm 120.2$ & 0.001 \\
\hline Carcass weight (g/bird) & $2505 \pm 55.7$ & $2439 \pm 55.7$ & 0.359 & $2975 \pm 55.7$ & $1969 \pm 55.7$ & 0.001 \\
\hline Dressing percentage (carcass as $\%$ of live weight) & $71.9 \pm 5.65$ & $79.9 \pm 5.65$ & 0.332 & $73.3 \pm 5.65$ & $78.5 \pm 5.65$ & 0.529 \\
\hline Breast meat percentage (breast as $\%$ of carcass) & $25.5 \pm 0.79$ & $25.5 \pm 0.79$ & 0.965 & $26.8 \pm 0.79$ & $24.3 \pm 0.79$ & 0.039 \\
\hline Leg meat percentage (leg meat as $\%$ of carcass) & $30.9 \pm 0.83$ & $29.7 \pm 0.83$ & 0.307 & $30.5 \pm 0.83$ & $30.1 \pm 0.83$ & 0.759 \\
\hline
\end{tabular}

$\mathrm{LSM} \pm \mathrm{SE}, N=20$ pens, 5 pens per genotype $\times$ diet treatment. The interaction between hybrid and diet was not significant $(P>0.05)$ for any of the variables presented in the table 


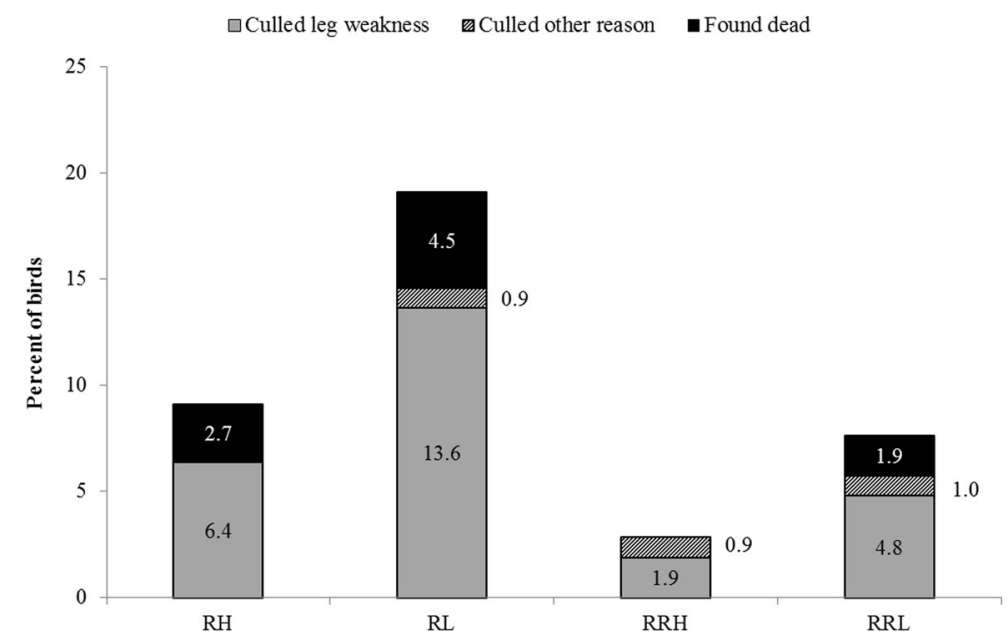

Fig. 2 Percentage of birds culled because of leg weakness, culled for other reasons, and found dead in the four genotype $\times$ diet treatment groups: fast-growing Ross birds fed the high-protein diet $(\mathrm{RH})$, fast-growing Ross birds fed the low-protein diet (RL),

findings on growth performance in fast- and slowgrowing hybrid birds (Castellini et al. 2002; Fanatico et al. 2005; Dal Bosco et al. 2014). For the fast-growing hybrid Ross, the average growth rate was lower then what is described in the performance objectives in the ROSS manual (Aviagen 2014), possibly because of the lower protein quality in organic diets compared to the conventional diets used in the ROSS manual performance evaluation. The average growth rate of the Ross hybrids was above the definition of a slow-growing breed currently stipulated by the Swedish organic organization KRAV (45 g/day) (KRAV 2016). The Rowan Ranger birds had an average growth rate just below the performance objectives in the Rowan Ranger manual (Aviagen 2016) and well below the $45 \mathrm{~g} /$ day limit. The feed conversion ratio was lower in the fast-growing Ross birds than in Rowan Ranger birds, leading to more efficient use of resources and thus potentially lower environmental impact from the fast-growing hybrid.

Several previous studies have shown a decrease in growth performance and carcass composition when the dietary protein content is diminished (e.g., Fancher and Jensen 1989; Pinchasov et al. 1990; Ferguson et al. 1998; Aletor et al. 2000). In the present study, the overall results showed no differences in daily weight gain, weight at slaughter, or carcass weight between the high- and low-protein diets. This discrepancy in results may be because previous studies investigated protein level differences of 3 to $4 \%$ between feeds, while in the present study, this difference was only $2.5 \%$. In fact, slow-growing Rowan Ranger birds fed the high-protein diet (RRH), and slow-growing Rowan Ranger birds fed the lowprotein diet (RRL)

more detailed investigations of the interactions between hybrid and diet showed that growth rate in the Ross birds was higher when these birds were fed the lowrather than the high-protein diet. In contrast, the Rowan Ranger birds had a higher growth when fed the highprotein diet. It could be reasoned that this difference in response to protein level in the diet between hybrids is caused by higher sensitivity to poor protein supply among Ross birds, adjusted by the birds through higher feed intake. In agreement with this reasoning, the results showed numerical tendency of, but not significantly, higher feed intake among Ross birds fed the low- than those fed the high-protein diet. Similarly, Han et al. (1992) and Canh et al. (1998) observed an increased weight gain when a low-protein diet was fed ad libitum to fast-growing hybrid broilers.

\section{Carcass characteristics}

Although there was a substantial difference in growth performance between the two hybrids, there were no differences in dressing percentage or percentage leg meat in the carcasses, and this is in agreement with previous studies (Castellini et al. 2002; Fanatico et al. 2008; Ristic et al. 2007). However, the percentage of breast meat in the carcass was higher in the Ross than in the Rowan Ranger birds. This indicates that there are differences between the two hybrids caused by years of genetic increase in breast meat quantity that have led to the 
present-day fast-growing broiler (Le Bihan-Duval et al. 1998; Rance et al. 2002).

Mortality and sticky droppings

A higher proportion of Ross birds was culled because of severe leg problems compared with Rowan Ranger birds, and birds fed the low-protein diet showed a tendency for a higher proportion of birds culled because of leg weakness compared to birds fed the high-protein diet. As seen in previous studies, rapid weight gain and excessive weight impair leg health (Weeks et al. 1994; Jones and Hocking 1999) and this is most likely the reason for the higher proportion of culled Ross birds in the present study. Regarding the tendency of differences between the low- and the high-protein diet, the qualitative nutrient restriction (i.e., the decreased protein content) had a negative effect on leg weakness and mortality in the present study, possibly explained by the higher feed consumption among Ross birds fed the low-protein diet. It could also have been the other way around that the higher mortality led to a higher average growth rate among birds fed the low-protein diet as more healthy birds survived. However, based on the findings from previous studies, taken together with the growth curves given in Fig. 1 and the fact that most of the mortality and culling occurred week $8-10$ of rearing, it is more likely that high growth rate caused mortality than that high mortality caused high average growth rate in the pens. The lower proportion of Rowan Ranger birds culled because of leg problems seen in the present study is in agreement with previous findings on slowergrowing hybrids (Bokkers and Koene 2003; Nielsen et al. 2003; Bessei 2006) and further supports the theory of weight induced leg weakness.

A sticky dropping is feces stuck around or close to the cloaca of the bird. Sticky droppings may be painful for the bird because of irritation to the sensitive skin and may cause dermatitis. A higher proportion of Ross birds had sticky droppings at 1 week of age compared with Rowan Ranger birds. This may have been caused by the higher feed intake. The diets were based on wheat and oats, of which the carbohydrate fraction contains arabinoxylans (AX) and $\beta$-glucan. These substances may create a viscous environment within the intestinal lumen and increase the incidence of wet and sticky droppings (Smits and Annison 1996).

\section{Conclusion}

The fast-growing Ross birds grew faster when fed the low-protein diet, and the slower-growing Rowan Ranger birds grew faster when fed the high-protein level diet, indicating differences in the response to dietary protein levels between these two hybrids. Although the Ross birds were more efficient from a feed conversion point of view, and therefore, in theory, more resource efficient, the high mortality and culling rate observed in Ross birds should also be considered in relation to resource efficiency. Furthermore, high mortality because of growth-related leg problems during the late rearing period in the Ross birds raises strong ethical concerns about using fast-growing birds in production systems with long rearing periods.

Acknowledgements This study was funded by grants from the Swedish Farmers' Foundation for Agricultural Research. The authors are grateful to the staff at the Swedish Livestock Research Centre, Swedish University of Agricultural Sciences, Uppsala, for their work with the broiler chickens in the experiment.

Compliance with ethical standards

All procedures were approved by the National Ethics Committee for Animal Experiments (C9/15, Uppsala, Sweden).

Open Access This article is distributed under the terms of the Creative Commons Attribution 4.0 International License (http://creativecommons.org/licenses/by/4.0/), which permits unrestricted use, distribution, and reproduction in any medium, provided you give appropriate credit to the original author(s) and the source, provide a link to the Creative Commons license, and indicate if changes were made.

\section{References}

Aletor VA, Hamid II, Niess E, Pfeffer E (2000) Low-protein amino acid-supplemented diets in broiler chickens: effects on performance, carcass characteristics, whole-body composition and efficiencies of nutrient utilisation. J Sci Food Agric 8: 547-554

Aviagen (2014) ROSS broiler management handbook. http://en. aviagen.com/assets/Tech_Center/Ross_Broiler/Ross-BroilerHandbook-2014i-EN.pdf

Aviagen (2016) Managing the Rowan Ranger. http://en.aviagen. com/assets/Uploads/RowanRangerManagement2016EN.pdf

Bessei W (2006) Welfare of broilers: a review. Worlds Poult Sci J $62: 455-466$

Blair R (2008) Nutrition and feeding of organic poultry, CAB Int., Oxfordshire, UK

Bokkers EAM, de Boer IJM (2009) Economic, ecological, and social performance of conventional and organic broiler production in the Netherlands. Br Poult Sci 50:546-557 
Bokkers EAM, Koene P (2003) Behaviour of fast-and slow-growing broilers to 12 weeks of age and the physical consequences. Appl Anim Behav Sci 81:59-72

Canh TT, Aarnink AJA, Schutte JB, Sutton A, Langhout DJ, Verstegen MWA (1998) Dietary protein affects nitrogen excretion and ammonia emission from slurry of growingfinishing pigs. Livest Prod Sci 56:181-191

Castellini C, Dal Bosco A, Mugnai C, Bernardini M (2002) Performance and behaviour of chickens with different growing rate reared according to the organic system. Ital J Anim Sci 1:291-300

Dal Bosco A, Mugnai C, Guarino Amato M, Piottoli L, Cartoni A, Castellini C (2014) Effect of slaughtering age in different commercial chicken genotypes reared according to the organic system: 1. Welfare, carcass and meat traits. It J Anim Sci 13:467-472

EC (2007) Council Regulation (EC) No 834/2007 of 28 June 2007 on organic production and labelling of organic products and repealing. Regulation (EEC) No 2092/91, Official Journal of the European Communities, L189/1 (20.07.2007)

Eriksson M, Waldenstedt L, Elwinger K, Engström B, Fossum O (2010) Behaviour, production and health of organically reared fast-growing broilers fed low crude protein diets including different amino acid contents at start. Acta Agric Scand Sect A Anim Sci 60(2):112-124

Fanatico AC, Pillai PB, Cavitt L, Owens CM, Emmert JL (2005) Evaluation of slower-growing broiler genotypes grown with and without outdoor access: growth performance and carcass yield. Poult Sci 84:1321-1327

Fanatico AC, Pillai PB, Hester PY, Falcone C, Mench JA, Owens CM, Emmert JL (2008) Performance, livability, and carcass yield of slow-and fast-growing chicken genotypes fed lownutrient or standard diets and raised indoors or with outdoor access. Poult Sci 87:1012-1021

Fancher BI, Jensen LS (1989) Influence on performance of three to six-week-old broilers of varying dietary protein contents with supplementation of essential amino acid requirements. Poult Sci 68:113-123

Ferguson NS, Gates RS, Taraba JL, Cantor AH, Pescatore AJ, Ford MJ, Burnham DJ (1998) The effect of dietary crude protein on growth, ammonia concentration, and litter composition in broilers. Poult Sci 77:1481-1487
Han Y, Suzuki H, Parsons CM, Baker DH (1992) Amino acid fortification of a low-protein corn and soybean meal diet for chicks. Poult Sci 71:1168-1178

Jones RB, Hocking PM (1999) Genetic selection for poultry behaviour: big bad wolf or friend in need? Anim Welf 8 : 343-359

KRAV (2016) KRAV standards. http://www.krav.se/kravstandards. KRAV, Uppsala, Sweden

Le Bihan-Duval E, Mignon-Grateau S, Millet N, Beaumont C (1998) Genetic analysis of a selection on increased body weight and breast muscle weight as well as on limited abdominal fat weight. Br Poult Sci 39:346-353

Morse D (1995) Environmental considerations of livestock producers. J Anim Sci 73:2733-2740

Moyle JR, Arsi K, Woo-Ming A, Arambel H, Fanatico A, Blore PJ, Clark FD, Donoghue DJ (2014) Growth performance of fast-growing broilers reared under different types of production systems with outdoor access: implications for organic and alternative production systems. J Appl Poult Res 23:1-9

Nielsen BL, Thomsen MG, Sørensen P, Young JF (2003) Feed and strain effects on the use of outdoor areas by broilers. Br Poult Sci 44:161-169

NRC (1994) Nutrient requirements of poultry, 9th rev edn. Nat. Acad. Press, Washington

Pinchasov Y, Mendonca CX, Jensen LS (1990) Broiler chick response to low-protein diets supplemented with synthetic amino acids. Poult Sci 69:1950-1955

Rance KA, McEntee GM, McDeitt RM (2002) Genetic and phenotypic relationships between and within support and demand tissues in a single line of broiler chicken. Br Poult Sci 43:518-527

Ristic M, Freudenreich P, Damme K, Werner R, Bittermann A, Schussler G, Kostner U, Ehrhardt S (2007) Meat quality of broilers: a comparison between conventional and organic production. Fleischwirtschaft 87:114-116

Smits CHM, Annison G (1996) Non-starch plant polysaccharides in broiler nutrition-towards a physiologically valid approach to their determination. World Poult Sci 52:203-221

Weeks CA, Nicol CJ, Sherwin CM, Kestin SC (1994) Comparison of the behaviour of broiler chicken in indoor and free-range environments. Anim Welf 3:179-192 